\title{
Academic Dishonesty in Computer and Mathematics Assignments
}

\author{
Mahmoud Abou Naaj, Mirna Nachouki
}

\begin{abstract}
This paper examines student perception toward ethical and unethical behaviors in mathematics and programming assignments. It further explores the impact of gender and grades on students' perception. Findings indicate that female students and students with CGPA greater than or equal to three appear to have higher ethics than their counterparts do. It also shows that there is no statistically significant difference in students' perception of what constitutes an academically dishonest behavior towards programming assignment and what constitutes an academically dishonest behavior towards mathematics assignment.
\end{abstract}

Index Terms: students' perception, academic dishonesty, cheating, plagiarism, collusion.

\section{INTRODUCTION}

Plagiarism and collusion have become a common practice among students in higher education across the globe, and information technology education is not an exception. Some writers use the single word 'plagiarism' to cover both. The distinction is important in IT disciplines, so we maintain the distinction in this paper, and define it briefly here. Both plagiarism and collusion involve using the work of others without properly attributing that work. With plagiarism, the 'others' are typically people that the student does not know, and the student has found their work in some public media such as a book, a journal, or the web. With collusion, the 'others' are typically people that the student knows, and who tend to collaborate with the student to produce the finished work. A typical example of plagiarism would be including in one's work something found on the web and not referencing it; a typical example of collusion would be two or more students in a class working together on an assessed task that is required to be done individually [1].

\section{LITERATURE REVIEW}

Plagiarism and collusion by university students is an area of concern to academics, both in their capacity as teachers and researchers [2]. Students are under enormous pressure from family, peer, instructors, and workplace. They often see education as a rung in the ladder to success, and not an active process valuable on the end results of their research, rather than the skill in doing it [3].

\section{A. Cheating in General}

A wide range of research over recent years has investigated academic dishonesty, ranging from exploring

Revised Manuscript Received on September 22, 2019.

Mahmoud Abou Naaj, Department of Information Technology/ College of Engineering and Information Technology/ Ajman University, Ajman, UAE.

Mirna Nachouki, Department of Information Technology/ College of Engineering and Information Technology/ Ajman University, Ajman, UAE. why students cheat to developing automatic methods of detecting those who do so [4], [5]. However, despite these efforts to combat inappropriate academic activity, successive investigations indicate that cheating among students remains a problem [6].

A nationwide study with a sample of 2,068 college students throughout Taiwan was selected and surveyed on the different domains of academic dishonesty, including, cheating on exams, cheating on assignment, plagiarism, and falsifying documents. Lin et al. [7] mentioned that around $61.72 \%$ of the surveyed students claimed that they had committed some type of academic dishonesty.

The context of higher education in Malaysia, is not an exception, the activities of academic dishonesty occur among students. Saidin et al. [8] reported that $82 \%$ of students plead admitted academic dishonesty.

\section{B. Factors influencing Academic dishonesty in higher education}

Many studies have tried to identify personal and environmental factors associated with cheating. According to McCabe \& al. [9], individual factors (gender, average grade, work ethics, self-esteem), institutional factors (faculty response to cheating, sanction threats, honor codes) and contextual factors (peer cheating behaviors, peer disapproval of cheating behaviors, severity of penalties for cheating) influence cheating behavior.

Giluk et al. [10] linked individual characteristics and situational factors to personal cheating characteristics such as age, gender, personality, extracurricular involvement, and ability; and situational factors such as honor codes, penalties, and risk of detection. The study of Jereb et al. revealed that specific individual characteristics of men and women influence plagiarism [11]. Newstead et al. [12] suggested three specific factors for plagiarism:

1. Gender differences (Plagiarism is more prevalent among boys),

2. Age differences (plagiarism is more prevalent among younger students), and

3. Academic performance differences (plagiarism is more prevalent among lower performers).

According to Gerdeman [13] the following five student characteristic variables are frequently related to the incidence of dishonest behavior: age, social activities, academic achievement, study major, and gender.

As for Howard [14] one of the factors influencing plagiarism could be that students do not have a clear understanding of what constitutes plagiarism and how it can be avoided. Park [15] states a genuine lack of understanding as one of the reasons for plagiarism. 
Some students plagiarize unintentionally because they are not familiar with proper ways of quoting, paraphrasing, citing and referencing. They are also unclear about the meaning of 'common knowledge' and the expression in their own words.

The study of Ramzan et al. [16] revealed that the societal and family pressures of getting higher grades influence plagiarism. Such pressure sometimes push students to plagiarism as a shortcut to performing better in exams or producing a certain number of publications. Engler et al. [17] tended to agree with this idea, stating that plagiarism arises out of social norms and peer relationships. Park [15] also stated that there are many calls on students' time, including peer pressure for maintaining an active social life, commitment to college sports and performance activities, family responsibilities, and pressure to complete multiple work assignments in short amounts of time. Franklin-Stokes et al. [18] mentioned another six significant reasons given by students to explain cheating behaviors: the desire to help a friend, a fear of failure, laziness, extenuating circumstances, the possibility of reaping a monetary reward, and because 'everybody does it. Park [15] mentioned students' academic skills (researching and writing skills, knowing how to cite, etc.) as another reason for plagiarism. New students and international students whose first language is not English need to transition to the research culture by understanding the necessity of doing research, and the practice and skills required to do so, to avoid unintentional plagiarism [16]. Other factors influencing plagiarizing are temptation and opportunity. It is both easier and more tempting for students to plagiarize since the information has become readily accessible, on the Internet and Web search tools, making it faster and easier to find information and copy it. Also, some students believe that since the Internet is free for all and a public domain, copying from the Internet requires no citation or acknowledgment of the source [19].

\section{Academic Dishonesty in Computer Science and Mathematics}

Several studies were dedicated to academic dishonesty, specifically within computer science. There are many reasons for this focus, and it has been shown that computer science accounts for more than its share of incidents. Whether the high rates of collusion and plagiarism incidents among computer science students are due to higher rates of dishonesty or due to better detection tools is open to debate. Barrett et al. [20] hypothesize that computer and mathematics science are subject to higher rates of collusion because of the nature of the work. While arts and humanities assignments typically involve personal reflection on the parts of the students, assignments in this discipline usually have an ideal solution, which the students are seeking. For the same reason, it is difficult to detect dishonesty amongst correct solutions; it is similar to incorrect or strange solutions that usually raise alarm bells. Striving to find the right solution can be an exhausting and frustrating experience.

There are clear reasons why general definitions and policies fail to cover computing assignments. Some of these are practical issues such as the fact that literally following university guidelines on attribution is likely to render a computer program syntactically incorrect [21]. However,

even accepting that externally sourced code cannot be placed in quotation marks, attribution is far from straightforward as, despite several initiatives, there is no standard, accepted format for appropriate attribution of externally sourced program code [22]. Other issues relate to the nature of the subject matter. The inter-textual similarities that arouse suspicion of text-based plagiarism are likely to be even more pronounced in coding assignments [23].

\section{Purpose Of The Study}

This study has two objectives:

1. To find out whether IT students have the same perception toward academic dishonesty in a programming assignment as they do in a mathematics assignment.

2. To find out whether factors like gender and grades are associated with cheating behaviors.

\section{RESEARCH QUESTIONS}

This study is guided by five research questions:

Research Question 1: Is there a significant difference in the mean score between students' perception as to what constitutes academically dishonest behavior towards programming assignment and what constitutes academically dishonest behavior towards mathematics assignment.

Research Question 2: Is there a significant difference in the mean score for students' perception between male and female students as to what constitutes academically dishonest behavior towards programming assignment.

Research Question 3: Is there a significant difference in the mean score for students' perception between male and female students as to what constitutes academically dishonest behavior towards mathematics assignment.

Research Question 4: Is there a significant difference in the mean score for students' perception between students with CGPA $<3$ and students with high grades CGPA $>=3$ as to what constitutes academically dishonest behavior towards programming assignment.

Research Question 5: Is there a significant difference in the mean score for students' perception between students with CGPA $<3$ and students with high grades CGPA $>=3$ as to what constitutes academically dishonest behavior towards Mathematics assignment.

\section{Methodology}

\section{A. Sample}

A self-administered survey was conducted in the academic year 2017/2018 on 270 undergraduate Information Technology (IT) students at Ajman University. A total of 209 students were found to complete the survey indicating $77.4 \%$. $54 \%$ were male, and $46 \%$ females. $49 \%$ of the respondents identified themselves to have CGPA of 3 or above and $51 \%$ with $C G P A<3$. Eighty five percent of the participants were less than 23 years of age. 


\section{B. Instrument}

The participants have completed the two sections of the survey. The first section collected demographical/personal data. The second section (Table I and Table II) consists of 12 items on the 5-point Likert scale, ranging from "1-very acceptable" to "5-very unacceptable". These items were mainly based on the survey used by Aasheim et al. [2]. The first three questions in tables I and table II are related to seeking authorized help while the last nine questions involve dishonest behavior.

Students have completed the survey form based on the following question: You are working on a graded programming or mathematics assignment for a class; your professor has told you this is an individual assignment. How acceptable are the following behaviors?

Table I. Students' behaviors Survey Form related to Programming Assignment

\begin{tabular}{|c|l|}
\hline$\#$ & \multicolumn{1}{|c|}{ ITEM } \\
\hline 1. & Asking the professor for help on the program \\
\hline 2. & $\begin{array}{l}\text { Asking a university teaching assistant for help on the } \\
\text { program }\end{array}$ \\
\hline 3. & $\begin{array}{l}\text { Reviewing similar programs in your textbook for ideas } \\
\text { on how to write your program. }\end{array}$ \\
\hline 4. & $\begin{array}{l}\text { Discussing ideas about the program with a fellow } \\
\text { student but implementing the ideas independently }\end{array}$ \\
\hline 5. & $\begin{array}{l}\text { Discussing ideas about the program on an Internet } \\
\text { newsgroup, social networking site, or blog. }\end{array}$ \\
\hline 6. & $\begin{array}{l}\text { Working together on the program with a fellow student } \\
\text { and submitting similar programs. }\end{array}$ \\
\hline 7. & $\begin{array}{l}\text { Copying a few lines of another student's program while } \\
\text { adding a significant portion of your own work. }\end{array}$ \\
\hline 8. & $\begin{array}{l}\text { Copying a few lines of the program from the Internet or } \\
\text { a textbook while adding a significant portion of your } \\
\text { own work. }\end{array}$ \\
\hline 9. & $\begin{array}{l}\text { Making minor changes to a program you had } \\
\text { previously written for another class and submitting it } \\
\text { for this class. }\end{array}$ \\
\hline 10. & $\begin{array}{l}\text { Posting the assignment on an Internet newsgroup, } \\
\text { social networking site, or blog, asking someone to } \\
\text { write the program for you. }\end{array}$ \\
\hline 11. & Hiring someone to write the program for you. \\
\hline 12. & $\begin{array}{l}\text { Copying another student's program, making minor } \\
\text { changes, and submitting it as your own. }\end{array}$ \\
\hline
\end{tabular}

\section{HyPothesis TeSTING}

\section{A. Comparing student Perception toward academic dishonesty in Mathematics and Programming Assignments}

H1: Students have no significant different perception as to what constitutes academically dishonest behavior towards programming assignments compared with mathematics assignment.

To determine whether students have different perceptions about what constitutes academically dishonest behavior towards programming assignments compared with mathematics assignment, a matched pair t-test was conducted. Table III presents the results for hypothesis H1.

The result of the matched pair t-test analysis shows that there is no significant difference in perceptions for programming assignment compared with mathematics assignment. Mathematics assignments Students' perception $(\mathrm{M}=2.92, \mathrm{SD}=1.26)$ and programming assignments students perception $(\mathrm{M}=3.01, \mathrm{SD}=1.19 ; \mathrm{t}(208)=-1.293, \mathrm{p}=0.393)$.

Thus, the hypothesis was accepted. This means there is no significant difference in students' perception toward mathematics assignment compared with programming assignment as to what constitutes academically dishonest behavior.

Table II. Students' behaviors Survey Form related to Mathematics Assignment

\begin{tabular}{|c|l|}
\hline$\#$ & \multicolumn{1}{|c|}{ ITEM } \\
\hline 1. & $\begin{array}{l}\text { Asking the professor for help on the mathematics } \\
\text { assignment. }\end{array}$ \\
\hline 2. & $\begin{array}{l}\text { Asking a university teaching assistant for help on the } \\
\text { mathematics assignment. }\end{array}$ \\
\hline 3. & $\begin{array}{l}\text { Reviewing similar problems in your textbook for ideas } \\
\text { on how to complete your mathematics assignment }\end{array}$ \\
\hline 4. & $\begin{array}{l}\text { Discussing ideas about the mathematics assignment } \\
\text { with a fellow student but implementing the solution } \\
\text { independently. }\end{array}$ \\
\hline 5. & $\begin{array}{l}\text { Discussing ideas about the mathematics assignment on } \\
\text { an Internet newsgroup, social networking site, or blog. }\end{array}$ \\
\hline 6. & $\begin{array}{l}\text { Working together on the mathematics assignment with } \\
\text { a fellow student and submitting similar work. }\end{array}$ \\
\hline 7. & $\begin{array}{l}\text { Copying a small part of another student's mathematics } \\
\text { assignment while adding a significant portion of your } \\
\text { own work. }\end{array}$ \\
\hline 8. & $\begin{array}{l}\text { Copying a small part of the mathematics assignment } \\
\text { from the Internet or a written source while adding a } \\
\text { significant portion of your own work. }\end{array}$ \\
\hline 9. & $\begin{array}{l}\text { Making minor changes to a mathematics assignment } \\
\text { you had previously completed for another class and } \\
\text { submitting it for this class. }\end{array}$ \\
\hline 10. & $\begin{array}{l}\text { Posting the mathematics assignment on an Internet } \\
\text { newsgroup, social networking site, or blog, asking } \\
\text { someone to solve the assignment for you. }\end{array}$ \\
\hline 11. & $\begin{array}{l}\text { Paying someone to solve the mathematics assignment } \\
\text { for you. }\end{array}$ \\
\hline 12. & $\begin{array}{l}\text { Copying another student's work, making minor } \\
\text { changes, and submitting it as your own. }\end{array}$ \\
\hline
\end{tabular}

\section{B. Gender Differences}

\section{Programming Assignment}

H2: There is no significant difference in students' perception between male and female students as to what constitutes academically dishonest behavior towards programming assignments.

To determine whether male and female students have different perceptions about what constitutes academically dishonest behavior towards programming assignments, an independent t-test was conducted. Table IV presents the result of the independent t-test for hypothesis $\mathrm{H} 2$.

Table III. Matched Pair t-Test Analysis

\begin{tabular}{|c|c|c|}
\hline Students' type & $\begin{array}{l}\text { Programming } \\
\text { Assignment }\end{array}$ & $\begin{array}{l}\text { Mathematics } \\
\text { Assignment }\end{array}$ \\
\hline Number of Participants & 209 & 209 \\
\hline
\end{tabular}




\begin{tabular}{|c|c|c|c|}
\hline \multicolumn{2}{|c|}{ mean } & 2.92 & 3.01 \\
\hline \multicolumn{2}{|c|}{ SD } & 1.26 & 1.19 \\
\hline \multicolumn{2}{|c|}{$\mathrm{t}$} & \multicolumn{2}{|c|}{-1.293} \\
\hline \multicolumn{2}{|c|}{ df } & \multicolumn{2}{|c|}{208} \\
\hline \multicolumn{2}{|c|}{$\mathrm{p}$} & \multicolumn{2}{|c|}{0.393} \\
\hline \multirow{2}{*}{$\begin{array}{c}95 \% \\
\text { Confidence } \\
\text { Interval of } \\
\text { the } \\
\text { Difference }\end{array}$} & Lower & \multicolumn{2}{|c|}{-0.94} \\
\hline & Upper & \multicolumn{2}{|c|}{-0.365} \\
\hline
\end{tabular}

The result of the independent t-test analysis shows that there is a statistically significant difference in male students' perception $(\mathrm{M}=2.293, \mathrm{SD}=.946)$ and female students' perception $(\mathrm{M}=2.69, \mathrm{SD}=1.15 ; \mathrm{t}(183)=-2.75, \mathrm{p}=0.0193)$ for authorized help in programming assignment. It shows also male students' perception $(\mathrm{M}=2.755, \mathrm{SD}=1.032)$ and female students' perception $(\mathrm{M}=3.445, \mathrm{SD}=1.16 ; \mathrm{t}(191)=$ -4.472, $\mathrm{p}=0.0035)$ for unauthorized help programming assignment. The hypothesis was rejected. This result means there is a significant difference in students' perception between male and female students as to what constitutes academically dishonest behavior towards Programming assignment. This result shows that female IT students have higher ethical behavior than their male counterpart.

Table IV. Independent Sample Test Analysis related to programming assignment.

\begin{tabular}{|c|c|c|c|c|c|}
\hline \multirow{2}{*}{\multicolumn{2}{|c|}{$\begin{array}{c}\text { Category } \\
\text { Students' type }\end{array}$}} & \multicolumn{2}{|c|}{$\begin{array}{c}\text { Authorized } \\
\text { help }\end{array}$} & \multicolumn{2}{|c|}{$\begin{array}{c}\text { unauthorized } \\
\text { help }\end{array}$} \\
\hline & & Male & Female & Male & Female \\
\hline \multicolumn{2}{|c|}{$\begin{array}{l}\text { Number of } \\
\text { Participants }\end{array}$} & 113 & 96 & 113 & 96 \\
\hline \multicolumn{2}{|c|}{ mean } & 2.293 & 2.69 & 2.755 & 3.445 \\
\hline \multicolumn{2}{|l|}{ SD } & 0.946 & 1.15 & 1.032 & 1.16 \\
\hline \multicolumn{2}{|l|}{$\mathrm{t}$} & \multicolumn{2}{|c|}{-2.75} & \multicolumn{2}{|c|}{-4.472} \\
\hline \multicolumn{2}{|l|}{ df } & \multicolumn{2}{|c|}{183} & \multicolumn{2}{|c|}{191} \\
\hline \multicolumn{2}{|l|}{$\mathrm{p}$} & \multicolumn{2}{|c|}{0.0193} & \multicolumn{2}{|c|}{0.0035} \\
\hline \multirow{2}{*}{$\begin{array}{c}95 \% \\
\text { Confidence } \\
\text { Interval of } \\
\text { the } \\
\text { Difference }\end{array}$} & Lower & \multicolumn{2}{|c|}{.- .69} & \multicolumn{2}{|c|}{-0.99} \\
\hline & Upper & \multicolumn{2}{|c|}{-0.113} & \multicolumn{2}{|c|}{-0.39} \\
\hline
\end{tabular}

\section{Mathematics Assignments}

H3: There is no significant difference in students 'perception between male and female students as to what constitutes academically dishonest behavior towards mathematics assignments.

To determine whether male and female students have different perceptions about what constitutes academically dishonest behavior towards mathematics assignments, an independent t-test was conducted. Table $\mathrm{V}$ presents the result of the independent t-test for hypothesis H3.
Table V. Independent Sample Test Analysis related to mathematics assignment.

\begin{tabular}{|c|c|c|c|c|c|}
\hline \multirow{2}{*}{\multicolumn{2}{|c|}{$\begin{array}{c}\text { Category } \\
\text { Students' type }\end{array}$}} & \multicolumn{2}{|c|}{$\begin{array}{l}\text { Authorized } \\
\text { help }\end{array}$} & \multicolumn{2}{|c|}{$\begin{array}{c}\text { Unauthorized } \\
\text { help }\end{array}$} \\
\hline & & Male & Female & Male & Female \\
\hline \multicolumn{2}{|c|}{$\begin{array}{l}\text { Number of } \\
\text { Participants }\end{array}$} & 113 & 96 & 113 & 96 \\
\hline \multicolumn{2}{|c|}{ mean } & 2.315 & 2.714 & 2.8 & 3.65 \\
\hline \multicolumn{2}{|c|}{ SD } & 1.1 & 1.066 & 1.1 & 1.16 \\
\hline \multicolumn{2}{|l|}{$\mathrm{t}$} & \multicolumn{2}{|c|}{-3.32} & \multicolumn{2}{|c|}{-5.73} \\
\hline \multicolumn{2}{|c|}{$\mathrm{df}$} & \multicolumn{2}{|c|}{203} & \multicolumn{2}{|c|}{196} \\
\hline \multicolumn{2}{|l|}{$\mathrm{p}$} & \multicolumn{2}{|c|}{0.005} & \multicolumn{2}{|c|}{0} \\
\hline \multirow{2}{*}{$\begin{array}{c}95 \% \\
\text { Confidence } \\
\text { Interval of } \\
\text { the } \\
\text { Difference } \\
\end{array}$} & Lower & \multicolumn{2}{|c|}{-.796} & \multicolumn{2}{|c|}{-1.212} \\
\hline & Upper & \multicolumn{2}{|c|}{-0.194} & \multicolumn{2}{|c|}{-0.59} \\
\hline
\end{tabular}

The result of the independent t-test analysis shows that there is a statistically significant difference in male students' perception $(\mathrm{M}=2.315, \mathrm{SD}=1.10)$ and female students' perception $(M=2.714, \mathrm{SD}=1.066 ; \mathrm{t}(203)=-3.32, \mathrm{p}=0.005)$ for authorized help in mathematics assignment. It shows also male students' perception $(\mathrm{M}=2.80, \mathrm{SD}=1.1)$ and female students' perception $(\mathrm{M}=3.65, \mathrm{SD}=1.16 ; \mathrm{t}(196)=-5.73, \mathrm{p}=$ $0.000)$ for unauthorized help mathematics assignment. The hypothesis was rejected. This result means there is a significant difference in students' perception between male and female students as to what constitutes academically dishonest behavior towards mathematics assignment. This result shows that female students have higher ethical behavior than their male counterpart.

\section{Grade Differences}

\section{Programming Assignment}

H4: There is no significant difference in students' perception between students with CGPA $<3$ and students with CGPA $>=3$ as to what constitutes academically dishonest behavior towards programming assignment.

To determine whether students with CGPA $\geq 3$ and students with CGPA $<3$ have different perceptions about what constitutes academically dishonest behavior towards programming assignments, an independent t-test was conducted. Table VI presents the result of the independent t-test for hypothesis $\mathrm{H} 4$.

The result of the independent t-test analysis shows that there is a statistically significant difference in students with CGPA $<3$ perception $(\mathrm{M}=2.30, \mathrm{SD}=0.993)$ and students with $C G P A \geq 3$ perception $(\mathrm{M}=2.66, \mathrm{SD}=1.146 ; \mathrm{t}(196)=$ $-2.47, \mathrm{p}=.016)$ for authorized help. It shows also that $(\mathrm{M}=$ $2.85, \mathrm{SD}=1.10)$ and students with $C G P A \geq 3$ perception $(\mathrm{M}=$ 3.30, $\mathrm{SD}=1.15 ; \mathrm{t}(204)=-2.914, \mathrm{p}=.009)$ for unauthorized help and copying. Thus, the hypothesis was rejected. This result means there is a significant difference in students' perception between students with $C G P A \geq 3$ and students with $C G P A<3$ as to what constitutes academically dishonest behavior towards Programming assignment. 
This result shows that students with CGPA $\geq 3$ from all IT programs have higher ethical behavior than those with CGPA $<3$.

\section{Mathematics Assignment}

H5: There is no significant difference in students' perception between students with CGPA $<3$ and students with CGPA $>=3$ as to what constitutes academically dishonest behavior towards mathematics assignment.

To determine whether students with CGPA $\geq 3$ and students with CGPA $<3$ have different perceptions about what constitutes academically dishonest behavior towards mathematics assignments, an independent t-test was conducted. Table VII presents the result of the independent t-test for hypothesis H5.

The result of the independent t-test analysis shows that there is a statistically significant difference in students with CGPA $<3$ perception $(\mathrm{M}=2.43, \mathrm{SD}=1.075)$ and students with $C G P A \geq 3$ perception $(\mathrm{M}=2.656, \mathrm{SD}=1.136 ; \mathrm{t}(205)=$ $-1.437, \mathrm{p}=.219$ ) for authorized help. The results also shows a significant difference in students with CGPA $<3$ perception $(\mathrm{M}=2.915, \mathrm{SD}=1.164)$ and students with $C G P A \geq 3$ perception $(\mathrm{M}=3.426, \mathrm{SD}=1.21 ; \mathrm{t}(203)=-3.11, \mathrm{p}=.009)$ for unauthorized help and copying. Thus, the hypothesis was accepted for authorized help, and rejected for unauthorized help and copying. This result means no significant difference in students' perception for authorized help, and there is a significant difference in students' perception for unauthorized help and copying between students with CGPA $\geq 3$ and students with $C G P A<3$ as to what constitutes academically dishonest behavior towards mathematics assignment. This result shows that students with CGPA $\geq 3$ from all IT programs have higher ethical behavior than those with CGPA $<3$.

Table VI. Independent Sample Test Analysis related programming assignment.

\begin{tabular}{|c|c|c|c|c|c|}
\hline \multicolumn{2}{|c|}{ Category } & \multicolumn{2}{|c|}{$\begin{array}{l}\text { Authorized } \\
\text { help }\end{array}$} & \multicolumn{2}{|c|}{$\begin{array}{c}\text { Unauthorized } \\
\text { help }\end{array}$} \\
\hline \multicolumn{2}{|c|}{ Students' type } & CGPA $<3$ & $\mathrm{CGPA} \geq 3$ & CGPA $<3$ & $\mathrm{CGPA} \geq 3$ \\
\hline \multicolumn{2}{|c|}{ Number of Participants } & 106 & 103 & 106 & 103 \\
\hline \multicolumn{2}{|c|}{ mean } & 2.3 & 2.66 & 2.85 & 3.3 \\
\hline \multicolumn{2}{|l|}{ SD } & 0.993 & 1.146 & 1.1 & 1.15 \\
\hline \multicolumn{2}{|l|}{$\mathrm{t}$} & \multicolumn{2}{|c|}{-2.477} & \multicolumn{2}{|c|}{-2.914} \\
\hline \multicolumn{2}{|l|}{ df } & \multicolumn{2}{|c|}{196} & \multicolumn{2}{|c|}{204} \\
\hline \multicolumn{2}{|l|}{$\mathrm{p}$} & \multicolumn{2}{|c|}{0.016} & \multicolumn{2}{|c|}{0.009} \\
\hline \multirow{2}{*}{$\begin{array}{c}95 \% \\
\text { Confidence } \\
\text { Interval of } \\
\text { the } \\
\text { Difference }\end{array}$} & Lower & \multicolumn{2}{|c|}{.- .6377} & \multicolumn{2}{|c|}{-0.76} \\
\hline & Upper & \multicolumn{2}{|c|}{-0.62} & \multicolumn{2}{|c|}{-0.145} \\
\hline
\end{tabular}

\section{DISCUSSION}

This research has contributed to the literature on academic dishonesty issues related to Mathematics assignment and computer programming assignments.

Results of this research indicate that there is no statistically significant difference between the perceptions for Mathematics assignments compared with programming assignment as to what constitutes academically dishonest behavior. These findings are consistent with past studies by Aasheim et al. [2].

Table VII. Independent Sample Test Analysis related to mathematics assignment.

\begin{tabular}{|c|c|c|c|c|}
\hline Category & \multicolumn{2}{|c|}{ Authorized help } & \multicolumn{2}{c|}{ Unauthorized help } \\
\hline Students' type & CGPA $<3$ & CGPA $\geq 3$ & CGPA $<3$ & CGPA $\geq 3$ \\
\hline $\begin{array}{c}\text { Number of } \\
\text { Participants }\end{array}$ & 106 & 103 & 106 & 103 \\
\hline mean & 2.433 & 2.656 & 2.915 & 3.426 \\
\hline SD & 1.075 & 1.136 & 1.164 & 1.21 \\
\hline $\mathrm{t}$ & \multicolumn{2}{|c|}{-1.437} & \multicolumn{2}{|c|}{-3.11} \\
\hline $\mathrm{df}$ & \multicolumn{2}{|c|}{205} & \multicolumn{2}{|c|}{203} \\
\hline $\mathrm{p}$ & \multicolumn{2}{|c|}{0.219} & \multicolumn{2}{|c|}{0.009} \\
\hline $\begin{array}{c}\text { 95\% } \\
\text { Confidence } \\
\text { nterval of the } \\
\text { Difference }\end{array}$ & Lower & \multicolumn{2}{|c|}{-.522} & \multicolumn{2}{|c|}{-0.836} \\
\hline
\end{tabular}

Results of this research indicate also that there is a statistically significant difference between the perception of female and male students as to what constitutes academically dishonest behavior. These findings are consistent with past studies indicating that female students have a higher level of ethics than their male counterparts [11], [9], [24]. On the other hand, studies by Andermanet et al. [25] and Chang et al. [26] found that male and female students have similar ethical perceptions and there is no significant difference between genders.

This study has revealed that there is a statistically significant difference related to academic performance. Students with CGPA $\geq 3$ have higher perception regarding what constitutes academically dishonest behavior. These results are consistent with the past findings by Newstead [12].

The literature review across similar studies concerning academic dishonesty identified inconsistent findings with respect to the impact of personal characteristics on students' propensity to cheat. These contradicting findings demonstrate that one's perception may vary when given in a different setting like different universities or different countries.

\section{LIMITATION}

This study focused on undergraduate IT students at Ajman University taking mathematics and programming courses. While valid, the results should not be over-generalized by the reader when applied to other majors or other institutions. In addition, the study used a self-reported questionnaire survey form, which is limited in nature by the accuracy of the participant's response. Although researchers took steps to facilitate accurate reporting, such as confidentiality and voluntary participation, these procedures might not have ruled out the bias associated with self-reported data, including social desirability. Despite the limitation of the instrument used, including socially desirable answers, self-report data is a powerful method to measure the level of students' perception. 


\section{Future STUdy}

Further research is needed to find the reasons behind the varying levels of perception in the areas discussed above to aid us in a better understanding of the factors influencing academic dishonesty and facilitate improvements in the quality learning of mathematics and programming courses and mathematics courses. Being able to understand the needs of students, to support students in learning in mathematics and programming courses, and to promote a successful learning experience will be critical to the overall success of learning in IT majors. Research should also be extended to include the investigation of instructor understanding of what constitutes an academically dishonest behavior. Further research is also needed to measure the extent of cheating at Ajman University, especially in different majors and the reason behind such behavior.

This study only focuses on IT students from Ajman University; hence, it is significant if it can be extended to include other IT students from different universities in the United Arab Emirates.

\section{REFERENCES}

1. D. Owunwanne, N. Rustagi and R. Dada, "Students' perceptions of cheating and plagiarism in higher institutions", Journal of College Teaching and Learning 7(11): 59-68, 2010.

2. C. Aasheim, P. Rutner, L. Lixin, and S. Williams, "Plagiarism and Programming: A Survey of Student Attitudes". Journal of Information Systems Education, Vol. 23(3). 297-313, 2012.

3. P. Sprajc, M. Urh, J. Jerebic, D. Trivan, and E. Jereb, "Reasons for plagiarism in higher education”, Organizacija. 50(1): 33-46, 2017.

4. D. McCabe, "Cheating and honor: lessons from a long-term research project", Handbook of Academic Integrity, Springer Science and Business Media, Singapore, 187-198, 2016.

5. R. R. Naik, M. B. Landge, and C. N. Mahender, "A review on plagiarism detection tools", International Journal of Computer Applications 125, 11, 2015.

6. M. O'Malley and T. S. Roberts, "Plagiarism on the rise? Combating contract cheating in science courses", International Journal of Innovation in Science and Mathematics Education, 20, 4, 2012.

7. C. H. S. Lin and L. Y. M. Wen, "Academic dishonesty in higher education-a nationwide study in Taiwan," Higher Education, vol. 54, pp. 85-97, 2007.

8. N. Saidin and N. Isa. "Investigating Academic Dishonesty among Language Teacher Trainee: The Why and How of Cheating", Procedia-Social and Behavioral Sciences, 90, 522-529, 2013.

9. D. L. McCabe, L. K. Trevino, and K. D. Butterfield, "Cheating in academic institutions: A decade of research", Ethics \& Behavior, 11(3), 219-232, 2001.

10. T.L. Giluk, and B.E. Postlethwaite, "Big Five personality and academic dishonesty: A meta-analytic review", Personality and Individual Differences, 72: 59-67, 2015.

11. E. Jereb, M. Urh, J. Jerebic, and P. Sprajc, "Gender differences and the awareness of plagiarism in higher education”, Social Psychology of Education. 2017. https://doi.org/10.1007/s11218-017-9421-y.

12. S. E. Newstead, A. Franklyn-Stokes, and P. Armestead, "Individual Differences in Student Cheating", Journal of Educational Psychology, 8(2), 22--241, 1996.

13. R.D. Gerdeman, "Academic dishonesty and the community college", ERIC Digest, ED447840, 2000. Available from: https://www.ericdigests.org/2001-3/college.htm.

14. R. Howard, and L.J. Davies, "Plagiarism in the Internet Age", Educational Leadership. 66(6): 64-67, 2009.

15. C. Park, "In other (people's) words: Plagiarism by university students literature and lessons", Assessment \& Evaluation in Higher Education, 28(5): 471-488, 2003.

16. M. Ramzan, M.A. Munir, N. Siddique, and M. Asif, "Awareness about plagiarism amongst university students in Pakistan", High Education, 64: 73-84, 2012.
17. J.N. Engler, J.D. Landau and M. Epstein, "Keeping up with the Joneses: Students' perceptions of academically dishonest behavior", Teaching of Pscychology, 35: 99-102, 2008.

18. A. Franklin-Stokes, and S. Newstead, "Undergraduate cheating: Who does what and why?", Studies in Higher Education, 20(2): 159-172, 1995.

19. S. Baruchson-Arbib, and E. Yaari, "Printed versus Internet plagiarism: A study of students' perception”, International Journal of Information Ethics, 1(6): 29-35 2004.

20. R. Barrett and A. L. Cox, "At least they are learning something: the hazy line between collaboration and collusion", Assessment \& Evaluation in Higher Education, 30 (2), 107-122, 2005.

21. G.F. Crown, and M.S. Spiller, "Learning from the literature on collegiate cheating: A review of empirical research", Journal of Business Ethics, 17: 683-700, 1998.

22. T.L. Giluk, and B.E. Postlethwaite, "Big Five personality and academic dishonesty: A meta-analytic review", Personality and Individual Differences, 72: 59-67, 2015.

23. S. Mann and Z. Frew, "Similarity and originality in code: plagiarism and normal variation in student assignments" Proceedings of the Eighth Australasian Computing Education Conference, 143-150, 2006.

24. S. A. Rodzalan and M. M. Saat, "Ethics of Undergraduate Students: A Study in Malaysian Public Universities", International Journal of Information and Education Technology, Vol. 6, No. 9, 2016.

25. E.M. Anderman, and C. Midgley, "Changes in self-reported academic cheating across the transition from middle school to high school". Contemporary Educational Psychology, 29: 499-517, 2004.

26. C.M. Chang, Y.L. Chen, Y. Huang, C. Chou, "Why do they become potential cyber-plagiarizers? Exploring the alternative thinking of copy-and-paste youth in Taiwan", Computers and Education, 87: 357-367, 2015.

\section{Authors Profile}

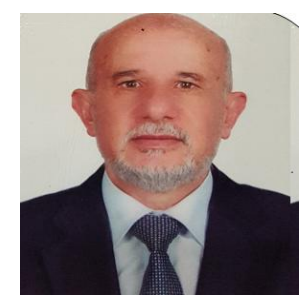

Mahmoud Abou Naaj, Ph.D. is an Associate Professor of Information Technology at Ajman University (AU). He has obtained his Ph.D. (1983), and MSc. (1979) in Computer Science from the University of Leeds (UK) and BSc (1975) in Mathematics from the University of Baghdad, Iraq. Currently, he is an associate professor at the College of Engineering and Information Technology, Department of Information Technology. He served as the dean of the College of General Studies, dean of the College of Information Technology and dean of Admission and Registration at AU. He has more than 34 years of teaching and research experiences. His current research interests include IT Education, Blended Learning, Assessments, Computer Ethics, and Computer Algorithms.

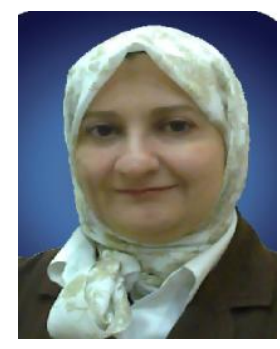

Mirna Nachouki, Ph.D. is an Assistant Professor and Head of the Information Technology Department in the College of Engineering and Information Technology at Ajman University (AU), Ajman - UAE. She was previously Acting Dean of the former College of Information Technology at AU. She obtained her B. Sc. in Computer Science from University of Pau (France) in 1988, her DEA (M. Sc.) and Ph. $\mathrm{D}$ in Computer Science in 1991 and 1995 respectively from University of Paul Sabatier, Toulouse III, France. Her expertise and research interest are in educational technologies, curriculum design and development, e-Learning standards, databases, and cloud computing. With over twenty years of professional experience, she has led many initiatives including the Information Systems program re-accreditation process that took place in 2006, 2011, and 2019 Dr. Mirna has been teaching also computer science related subjects such as programming, object oriented, computer graphics, data structures and algorithms, database management systems, software engineering, concepts of programming languages, etc. for the past twenty years at AU 